\title{
The Effect of Application of Ethephon to Processing Tomato Plants on the Chemical Composition of Fruits
}

\author{
Maria GAWĘDA ${ }^{1}$, Elżbieta JĘDRSZCZYK ${ }^{1 *}$, Barbara SKOWERA², \\ Renata JĘDRZEJCZAK ${ }^{3}$, Krystyna SZYMCZYK ${ }^{3}$ \\ ${ }^{1}$ University of Agriculture, Faculty of Biotechnology and Horticulture, Department of Vegetable and Medicinal Plants, al. 29 Listopada 54, \\ 31-425Kraków,Poland;m.gaweda@ogr.ur.krakow.pl; e.jedrszczyk@ogr.ur.krakow.pl ( ${ }^{*}$ correspondingauthor) \\ ${ }^{2}$ University of Agriculture, Faculty of Environmental Engineering and Land Surveying, Climatology and Air Protection, Department of Ecology, \\ al. Mickiewicza 24/28,30-059 Kraków, Poland; rmskower@cyf-kr.edu.pl \\ ${ }^{3}$ Institute of Agricultural and Food Biotechnology, Department of Food Analysis, Rakowiecka 36, 02-532 Warsaw, \\ Poland;jedrzejczak@ibprs.pl;szymczyk@ibprs.pl
}

\begin{abstract}
Ethephon is used to accelerate fruit ripening on plantations with well-developed plants which have formed a large quantity of fruits. The aim of the study was to determine the effect of ethephon on the chemical composition of the fruits of seven cultivars of processing tomato ('Rumba', 'Hubal', 'Sokal' $F_{1}$, 'Mieszko' $F_{1}$, 'Polset' $F_{1}$, 'Hysioux' $F_{1}$ and 'AF1120' $F_{1}$ ), applied to the plants when most of the fruits had reached the mature-green stage. The study was conducted during three consecutive years, characterized by different weather conditions. Meteorological elements, i.e. air temperature and precipitation totals, were monitored in the experimental station in Mydlniki, near Krakow, Poland. Ethephon was found to have a beneficial effect on the content of extract and soluble sugars of the harvested tomatoes and on their acidity. Dry matter and lycopene levels were not dependent on the use of this compound, while the ascorbic acid content was reduced by the procedure. The chemical composition of the tomato fruits differed significantly in consecutive years of the study, which confirmed the weather impact on fruit quality and on the varied responses of different cultivars to use of ethephon. The tested cultivars were also compared in terms of their suitability for processing. The 'Hubal' cultivar had the highest content of dry matter, extract, soluble sugars of all the cultivars tested. The highest level of lycopene was noted for the tomatoes of the 'Rumba' and 'Sokal' $F_{1}$ cultivar, ascorbic acid of the 'Rumba' and the highest acidity for 'AF 1120 ' $\mathrm{F}_{1}$.
\end{abstract}

Keywords: acidity, cultivar, dry matter, lycopene, meteorological elements, sugars, vitamin C

\section{Introduction}

In the cultivation of tomatoes the application of ethephon (2-chloroethylphosphonic acid) during the mature-green stage accelerates fruit ripening. It decomposes to ethylene, with the rate of decomposition depending on $\mathrm{pH}$, temperature, concentration, and the degree of penetration of the tomato tissue (Saltveit, 2005a). When the fruits reach the breaker stage, internally synthesized ethylene sustains its own synthesis and stimulates ripening, even when the external concentration of ethylene has dropped to zero. Ethylene, produced autocatalytically as a result of expression of two key enzymes ACC syntase (ACS) and ACC oksydase (ACO) (Lelievre et al., 1997) in climacteric fruits, is received by receptors activating hundreds of genes, leading to chlorophyll degradation and synthesis of other pigments (carotenoids and anthocyanins), conversion of starches to sugars, and production of aromatic compounds and numerous secondary metabolites (Payasi and Sanwal, 2010). Changes in the firmness of tomatoes under the influence of ethephon should be associated with an increase of the activity of polygalacturonase and degradation of protopectin in cell wall (Li et al., 2016).

Under the optimal temperature conditions, application of ethephon to the plants is not considered essential, but it seems to be necessary in cooler years (Gonzales, 1999). Tomato fruits treated with ethephon are harvested several days earlier and the harvest window is considerably reduced (Logendra $e t$ al., 2004). Depending on the amount applied (500-1,000 ppm) the acceleration ranges from 2 to 6 days (Moniruzzman et al., 2015). Factors determining the response of the plant to 
ethylene are its species and cultivar, stage of development, cultivation techniques, stress factors, the concentration of the agent, exposure time, temperature and humidity (Saltveit, 1999). The use of ethephon reduces the susceptibility of the fruits to Botrytis cinerea, as it increases their resistance to disease (Wanga et al., 2011).

Harvesting of tomatoes, during the green or breaker phase, yields a product of inferior flavour, because the content of acids is higher and the content of sugars is lower than the optimal level. The red phase is considered to be the best time to harvest of the fruit (Beckles, 2012). During ripening of tomatoes from the mature-green phase to the red-ripe phase, there is an increase in the content of extract, reducing sugars, organic acids, ascorbic acid and lycopene (Saltveit, 2005b), as well as in antioxidant activity (Ilahy et al., 2011).

In Poland, tomatoes for processing are grown in the open field, not only for economic reasons but also due to the better quality of the fruit produced. Dumas et al. (2003) report that field-grown tomatoes usually have more lycopene and vitamin $\mathrm{C}$ than tomatoes grown under cover (in tunnels or greenhouses). Annual production of field tomatoes in Poland is 400,000-500,000 tonnes (Kmiecik and Lisiewska, 2000). As weather conditions have a decisive influence on tomato ripening, they should be harvested by mid to late September, before the onset of autumn frosts (Rożek et al., 2011). Ethephon is used to accelerate fruit ripening on plantations with well-developed plants which have formed a large quantity of fruit. The preparation is applied once, when $5-15 \%$ of fruits on the plants are in the pink or turning stage and $50-70 \%$ is in the mature-green stage. Tomatoes for processing are harvested in the red-ripe stage. Acceleration of ripening with ethephon affects the chemical composition of fruit (synthesis of sugars and organic acids, flavour and aroma) (Kenavy et al., 2008, Payasi and Sanwal, 2010, Dhall and Singh, 2013). Many authors also emphasize the varied reactions of different cultivars to the use of ethylene (Orłowski et al., 2005).

The aim of the study was to determine the effect of ethephon on the chemical composition of the fruits of seven processing tomato cultivars applied to the plants when most of the fruit had reached the mature-green phase and to compared their quality with the quality of tomatoes not treated with this compound.

\section{Materials and Methods}

\section{Experimental procedures}

The experiment was conducted in an open field at the Experimental Station of the Department of Vegetable and Medicinal Plants in Mydlniki, near Krakow, Poland, in the years 2009-2011. Tomato plants were cultivated from transplants. The seedlings were planted at $80 \times 60 \mathrm{~cm}$ spacing at different times each year, depending on weather conditions - 21.05.2009, 29.05.2010, and 16.05.2011. May of 2010 was extremely wet (302 mm of precipitation), which delayed planting. During the growing season the typical treatments, such as weed management and chemical protection against diseases, were carried out according to current recommendations. The experiment was set up as a split-block design with four replications. Each plot had an area of $57.6 \mathrm{~m}^{2}$. The mature fruit was harvested on 7.09.2009, 14.09.2010 and 30.08.2011.
Plantmaterial

In 2009 five cultivars of processing tomato, 'Rumba' and 'Hubal' (Ożarów), 'Sokal' $F_{1}$ and 'Mieszko' $F_{1}$ (PlantiCo), and 'Polset' $F_{1}$ (Bejo Zaden), were studied. In 2010 and 2011, the cultivars 'Hysioux' $F_{1}$ and 'AF1120' $F_{1}$ (Western Seeds) were additionally introduced to the study.

\section{Ethephon application procedures}

Ethephon was applied as an aqueous formulation of the active ingredient of Agrostym 480 SL (Bayer SAS). The ethephon present in Agrostym $480 \mathrm{SL}$ in an acidic environment is constant. In the plant tissue, where the $\mathrm{pH}$ is higher, it is decomposed to ethylene. Two weeks before harvesting half of the plants of each cultivar were sprayed with Agrostym $480 \mathrm{SL}\left(31 \mathrm{ha}^{-1}\right)$ and half were left as a control without spraying.

\section{Meteorological background}

Meteorological elements, i.e. air temperature and precipitation totals, were monitored on the experimental plots. Data on daily precipitation totals, the number of days with precipitation, and mean air temperature, as well as long-term data from 1981-2010, were obtained from the nearby KrakówBalice meteorological station (Table 1).

The year 2009 was the most favourable according temperatures and sum and the frequency of precipitation compared to the period of 1981-2010.

\section{Analysis of chemical composition}

Twenty red-ripe fruits were collected for analysis from the marketable yield of each cultivar of the ethephon and control treatments. The content of chemical components of the tomato fruits was tested in three replications. The following parameters were determined:

- dry matter (\% FW) was determined by the oven-dry method (Pijanowski et al., 2004).

- total acidity (\% FW) was determined by the titration method using sodium hydroxide (Pijanowski $e t$ al., 2004).

- l-ascorbic acid (mg\%) was determined according to Tillmans by titration of extracts with indophenol solution (PN-71/A/75101).

- extract ( ${ }^{\circ}$ Brix) was determined with a WYA Abbe refractometer in juice squeezed from the fruits (PN90/A-75101/02).

- soluble sugars (\% FW) were analysed by the anthrone colorimetric method (Yemm and Wills, 1954) following extraction with ethyl alcohol, and their extinction was determined with a UV-VIS Helios $\beta$ spectrophotometer.

- lycopene content was determined only in 2009 and 2010 by HPLC-UV. Lycopene was extracted with a mixture of $100 \mathrm{ml}$ methanol and $100 \mathrm{ml}$ chloroform; after separation of phases the chloroform phase was collected. The extract was evaporated under a stream of nitrogen at the lowest possible temperature and chromatographic analysis was performed in a highpressure liquid chromatography kit by Thermo Separation. Lycopene content was calculated by the external standard method using integration software in conjunction with a high-pressure liquid 
486

Table 1. The characteristics of the air temperature and the precipitation in Kraków-Mydlniki

\begin{tabular}{|c|c|c|c|c|c|c|}
\hline Meteorological elements & Years & May & June & July & August & September \\
\hline \multirow{4}{*}{ Mean temperature $\left({ }^{\circ} \mathrm{C}\right)$} & $1981-2010$ & 14.0 & 16.8 & 18.8 & 18.2 & 13.5 \\
\hline & 2009 & 13.5 & 16.0 & 19.9 & 18.7 & 15.1 \\
\hline & 2010 & 12.8 & 17.5 & 20.7 & 18.4 & 12.1 \\
\hline & 2011 & 12.7 & 18.6 & 17.9 & 19.4 & 12.4 \\
\hline \multirow{4}{*}{ Total precipitation $(\mathrm{mm})$} & $1981-2010^{*}$ & 81 & 87 & 88 & 77 & 63 \\
\hline & 2009 & 106 & 140 & 83 & 53 & 35 \\
\hline & 2010 & 302 & 122 & 110 & 138 & 82 \\
\hline & 2011 & 49 & 41 & 163 & 37 & 14 \\
\hline \multirow{4}{*}{ Number of days with precipitation } & $1981-2010^{*}$ & 12 & 12 & 13 & 11 & 10 \\
\hline & 2009 & 17 & 21 & 15 & 10 & 11 \\
\hline & 2010 & 27 & 13 & 13 & 17 & 18 \\
\hline & 2011 & 11 & 14 & 22 & 10 & 6 \\
\hline
\end{tabular}

experimental station Kraków-Mydlniki.

Table 2. Changes in dry matter content (\% f.w.) in tomato fruits after ethephon application

\begin{tabular}{|c|c|c|c|c|c|c|}
\hline \multirow{2}{*}{ Cultivar } & \multicolumn{2}{|c|}{2009} & \multicolumn{2}{|c|}{2010} & \multicolumn{2}{|c|}{2011} \\
\hline & Control & Ethephon & Control & Ethephon & Control & Ethephon \\
\hline Rumba & $5.92 \mathrm{bcd}$ & $5.71 \mathrm{abc}$ & $4.30 \mathrm{ab}$ & $4.65 \mathrm{bc}$ & $5.41 \mathrm{ab}$ & $5.12 \mathrm{a}$ \\
\hline Sokal F & $5.40 \mathrm{a}$ & $5.69 \mathrm{abc}$ & $4.88 \mathrm{c}$ & $4.82 \mathrm{c}$ & $6.03 \mathrm{de}$ & $5.68 \mathrm{bcd}$ \\
\hline Mieszko $F_{1}$ & $5.53 \mathrm{ab}$ & $6.15 \mathrm{de}$ & $4.99 c$ & $5.01 \mathrm{c}$ & $5.86 \mathrm{~cd}$ & $5.54 \mathrm{abc}$ \\
\hline Hubal & $5.60 \mathrm{~cd}$ & $6.53 \mathrm{e}$ & $4.91 \mathrm{c}$ & $4.90 \mathrm{c}$ & $6.05 \mathrm{de}$ & $5.99 \mathrm{de}$ \\
\hline Polset $F_{1}$ & $5.54 \mathrm{abc}$ & $5.85 \mathrm{bcd}$ & $4.21 \mathrm{a}$ & $4.65 \mathrm{bc}$ & $5.46 \mathrm{abc}$ & $5.54 \mathrm{abc}$ \\
\hline $\mathrm{AF} 1120 \mathrm{~F}_{1}$ & - & - & $5.46 \mathrm{~d}$ & $4.90 \mathrm{c}$ & $6.55 \mathrm{f}$ & $6.34 \mathrm{ef}$ \\
\hline Hysioux $F_{1}$ & - & - & $4.76 c$ & $4.91 \mathrm{c}$ & $5.72 \mathrm{bcd}$ & $5.75 \mathrm{bcd}$ \\
\hline Mean & $5.69 \mathrm{~A}$ & $5.98 \mathrm{~B}$ & $4.79 \mathrm{~A}$ & $4.803 \mathrm{~A}$ & $5.87 \mathrm{~B}$ & $5.71 \mathrm{~A}$ \\
\hline
\end{tabular}

Table 3. Changes in extract content (\% f.w.) in tomato fruits after ethephon application

\begin{tabular}{|c|c|c|c|c|c|c|}
\hline \multirow{2}{*}{ Cultivar } & \multicolumn{2}{|c|}{2009} & \multicolumn{2}{|c|}{2010} & \multicolumn{2}{|c|}{2011} \\
\hline & Control & Ethephon & Control & Ethephon & Control & Ethephon \\
\hline Rumba & $4.93 \mathrm{~b}$ & $4.85 \mathrm{~b}$ & $3.89 \mathrm{a}$ & $4.15 b c$ & $4.65 \mathrm{ab}$ & $4.55 \mathrm{ab}$ \\
\hline Sokal Fl & $4.40 \mathrm{a}$ & $4.70 \mathrm{~b}$ & $4.19 \mathrm{~cd}$ & $3.89 \mathrm{a}$ & $4.95 \mathrm{bc}$ & $4.63 \mathrm{ab}$ \\
\hline Mieszko $F_{1}$ & $4.30 \mathrm{a}$ & $5.20 \mathrm{c}$ & $4.19 \mathrm{~cd}$ & $4.40 \mathrm{e}$ & $4.75 \mathrm{abc}$ & $4.50 \mathrm{a}$ \\
\hline Hubal & $5.23 c$ & $5.80 \mathrm{~d}$ & $4.59 \mathrm{f}$ & $4.39 \mathrm{e}$ & $5.65 \mathrm{e}$ & $5.60 \mathrm{e}$ \\
\hline Polset $F_{1}$ & $4.43 \mathrm{a}$ & $5.23 c$ & $3.84 \mathrm{a}$ & $4.00 \mathrm{ab}$ & $5.45 \mathrm{de}$ & $4.85 \mathrm{abc}$ \\
\hline $\mathrm{AF} 1120 \mathrm{~F}_{1}$ & - & - & $4.59 \mathrm{f}$ & $4.68 \mathrm{f}$ & $5.50 \mathrm{de}$ & $5.40 \mathrm{de}$ \\
\hline Hysioux $F_{1}$ & - & - & $4.34 \mathrm{de}$ & $4.30 \mathrm{cde}$ & $5.10 \mathrm{~cd}$ & $4.90 \mathrm{abc}$ \\
\hline Mean & $4.66 \mathrm{~A}$ & $5.16 \mathrm{~B}$ & $4.23 \mathrm{~A}$ & $4.26 \mathrm{~A}$ & $5.15 \mathrm{~B}$ & $4.92 \mathrm{~A}$ \\
\hline
\end{tabular}

chromatograph, taking into account the size of the weighted sample, the volume of extract collected and the degree of dilution of the sample.

\section{Statistical procedures}

The results were statistically analysed using the analysis of variance for double classification by Tukey's HSD test, with $p$ $<0.05$ in Statistica Software. The differences in the chemical composition of the tomato fruits following application of ethephon (mean for years and cultivars), in each year of the study (mean for cultivars and ethephon) and each cultivar (mean for years and ethephon) were determined by Tukey's HSD test for unequal N. This test was chosen because the number of cultivars was not the same in each year of the study.

\section{Results}

The average dry matter of the harvested tomatoes after spraying with ethephon was $5.1 \%$ higher for the cultivars in
2009, unchanged in 2010, and $2.7 \%$ lower in 2011. The response of individual cultivars to the use of ethephon varied. The content of dry matter, after spraying with the preparation, increased in the fruits of the 'Mieszko' F1, 'Hubal' and 'Polset' F1 cultivars in 2009, and in 'Rumba' and 'Polset' F1 in 2010, but in 2011 the treatment did not increase dry matter in the fruits; in fact, a decrease in dry matter was noted in the 'Sokal' F1 and 'Mieszko' F1 cultivars (Table 2).

Content of extract, after spraying with ethephon, increased by $10.7 \%$ in 2009 , remained unchanged in 2010 , and decreased by $4.5 \%$ in 2011. In 2009 application of ethephon caused an increase in extract in the fruits of most of the cultivars examined, while in 2010 an increase was noted only in 'Rumba' and 'Mieszko' $F_{1}$ fruits. In 2011 no effect of ethephon on this trait was observed, with the exception of 'Polset' $F_{1}$ and 'Hysioux' $F_{1}$, in which a decrease in extract was noted in the fruits from the sprayed plots (Table 3).

Differences noted in the content of soluble sugars in the fruits of individual cultivars were depending on the application 
Table 4. Changes in soluble sugars content (\% f.w.) in tomato fruits after ethephon application

\begin{tabular}{|c|c|c|c|c|c|c|}
\hline \multirow{2}{*}{ Cultivar } & \multicolumn{2}{|c|}{2009} & \multicolumn{2}{|c|}{2010} & \multicolumn{2}{|c|}{2011} \\
\hline & Control & Ethephon & Control & Ethephon & Control & Ethephon \\
\hline Rumba & $1.98 \mathrm{bc}$ & $2.29 \mathrm{bcd}$ & $1.32 \mathrm{~b}$ & $1.59 \mathrm{c}$ & $1.25 \mathrm{fg}$ & $1.11 \mathrm{bcd}$ \\
\hline Sokal $F_{1}$ & $1.64 \mathrm{ab}$ & $1.07 \mathrm{a}$ & $1.96 \mathrm{fg}$ & $1.35 \mathrm{~b}$ & $1.02 \mathrm{ab}$ & $1.12 \mathrm{cde}$ \\
\hline Mieszko $F_{1}$ & $1.90 \mathrm{bc}$ & $2.14 \mathrm{bcd}$ & $1.82 \mathrm{cdef}$ & $1.69 \mathrm{cde}$ & $1.24 \mathrm{fg}$ & $1.27 \mathrm{~g}$ \\
\hline Hubal & $1.98 \mathrm{bc}$ & $2.81 \mathrm{~d}$ & $2.19 \mathrm{~g}$ & $1.72 \mathrm{cde}$ & $1.28 \mathrm{~g}$ & $1.14 \mathrm{cde}$ \\
\hline Polset $F_{1}$ & $1.89 \mathrm{bc}$ & $2.37 \mathrm{~cd}$ & $0.98 \mathrm{a}$ & $1.88 \mathrm{ef}$ & $1.05 \mathrm{abc}$ & $1.21 \mathrm{efg}$ \\
\hline $\mathrm{AF} 1120 \mathrm{~F}_{1}$ & - & - & $1.78 \mathrm{cdef}$ & $1.61 \mathrm{~cd}$ & $1.17 \mathrm{def}$ & $1.13 \mathrm{cde}$ \\
\hline Hysioux $F_{1}$ & - & - & $1.74 \mathrm{cdef}$ & $1.84 \mathrm{def}$ & $1.08 \mathrm{bc}$ & $0.96 \mathrm{a}$ \\
\hline Mean & $1.88 \mathrm{~A}$ & $2.13 \mathrm{~A}$ & $1.68 \mathrm{~A}$ & $1.67 \mathrm{~A}$ & $1.16 \mathrm{~A}$ & $1.14 \mathrm{~A}$ \\
\hline
\end{tabular}

Note: Values marked with the same letter within the same years and means for years do not differ significantly (Tukey's HSD test, $\mathrm{p}<0.05)$

Table 5. Changes in total acidity content (\% f.w.) in tomato fruits after ethephon application

\begin{tabular}{|c|c|c|c|c|c|c|}
\hline \multirow{2}{*}{ Cultivar } & \multicolumn{2}{|c|}{2009} & \multicolumn{2}{|c|}{2010} & \multicolumn{2}{|c|}{2011} \\
\hline & Control & Ethephon & Control & Ethephon & Control & Ethephon \\
\hline Rumba & $0.35 \mathrm{c}$ & $0.34 \mathrm{bc}$ & 0.44 ef & $0.40 \mathrm{cde}$ & $0.32 \mathrm{a}$ & $0.35 \mathrm{ab}$ \\
\hline Sokal F $F_{1}$ & $0.35 \mathrm{c}$ & $0.38 \mathrm{~d}$ & $0.34 \mathrm{a}$ & $0.39 \mathrm{bcd}$ & $0.38 \mathrm{abc}$ & $0.38 \mathrm{abc}$ \\
\hline Mieszko $F_{1}$ & $0.29 \mathrm{a}$ & $0.34 \mathrm{bc}$ & $0.35 \mathrm{ab}$ & $0.37 \mathrm{abc}$ & $0.34 \mathrm{ab}$ & $0.35 \mathrm{ab}$ \\
\hline Hubal & $0.32 \mathrm{~b}$ & $0.32 \mathrm{~b}$ & $0.42 \mathrm{def}$ & $0.39 \mathrm{bcd}$ & $0.38 \mathrm{abc}$ & $0.40 \mathrm{bc}$ \\
\hline Polset $F_{1}$ & $0.32 \mathrm{~b}$ & $0.45 \mathrm{e}$ & $0.53 \mathrm{~h}$ & $0.45 \mathrm{fg}$ & $0.38 \mathrm{abc}$ & $0.40 \mathrm{bc}$ \\
\hline $\mathrm{AF} 1120 \mathrm{~F}_{1}$ & - & - & $0.45 \mathrm{fg}$ & $0.48 \mathrm{~g}$ & 0.42 c & $0.51 \mathrm{~d}$ \\
\hline Hysioux $F_{1}$ & - & - & $0.42 \mathrm{def}$ & 0.40 cde & $0.42 c$ & $0.38 \mathrm{abc}$ \\
\hline Mean & $0.33 \mathrm{~A}$ & $0.36 \mathrm{~B}$ & $0.42 \mathrm{~A}$ & $0.41 \mathrm{~A}$ & $0.38 \mathrm{~A}$ & $0.40 \quad \mathrm{~B}$ \\
\hline
\end{tabular}

Note: Values marked with the same letter within the same years and means for years do not differ significantly (Tukey's HSD test, $\mathrm{p}<0.05)$

Table 6. Changes in L-ascorbic acid content (\% f.w.) in tomato fruits after ethephon application

\begin{tabular}{|c|c|c|c|c|c|c|}
\hline \multirow{2}{*}{ Cultivar } & \multicolumn{2}{|c|}{2009} & \multicolumn{2}{|c|}{2010} & \multicolumn{2}{|c|}{2011} \\
\hline & Control & Ethephon & Control & Ethephon & Control & Ethephon \\
\hline Rumba & $20.50 c$ & $22.25 \mathrm{de}$ & $27.63 \mathrm{~h}$ & $26.55 \mathrm{~h}$ & $27.25 \mathrm{e}$ & $25.65 \mathrm{de}$ \\
\hline Sokal $F_{1}$ & $17.10 \mathrm{~b}$ & $16.75 \mathrm{ab}$ & $24.13 \mathrm{~g}$ & $14.90 \mathrm{abc}$ & $22.10 \mathrm{c}$ & $26.65 \mathrm{de}$ \\
\hline Mieszko $F_{1}$ & $15.22 \mathrm{a}$ & $18.15 b$ & $14.25 \mathrm{ab}$ & 17.78 ef & $24.35 \mathrm{~cd}$ & $24.50 \mathrm{~cd}$ \\
\hline Hubal & $23.13 \mathrm{e}$ & $20.20 c$ & $23.60 \mathrm{~g}$ & $23.78 \mathrm{~g}$ & $19.50 \mathrm{~b}$ & $15.25 \mathrm{a}$ \\
\hline Polset $F_{1}$ & $20.50 \mathrm{c}$ & $21.20 \mathrm{~cd}$ & $13.90 \mathrm{a}$ & $15.93 \mathrm{cde}$ & $23.35 \mathrm{~cd}$ & $25.65 \mathrm{de}$ \\
\hline $\mathrm{AF} 1120 \mathrm{~F}_{1}$ & - & - & $16.70 \mathrm{def}$ & $16.20 \mathrm{cde}$ & $31.85 \mathrm{f}$ & $22.10 \mathrm{c}$ \\
\hline Hysioux $F_{1}$ & - & - & 17.23 ef & $15.50 \mathrm{bcd}$ & $23.05 c$ & $17.20 \mathrm{ab}$ \\
\hline Mean & $19.29 \mathrm{~A}$ & $19.71 \mathrm{~A}$ & $19.63 \mathrm{~B}$ & $18.67 \mathrm{~A}$ & $24.49 \mathrm{~B}$ & $22.29 \quad \mathrm{~A}$ \\
\hline
\end{tabular}

Table 7. Changes in lycopene content (\% f.w.) in tomato fruits after ethephon application

\begin{tabular}{lcccc}
\hline \multirow{2}{*}{ Cultivar } & \multicolumn{2}{c}{2009} & \multicolumn{2}{c}{2010} \\
\cline { 2 - 5 } & Control & Etephon & Control & Etephon \\
\hline Rumba & $241.5 \mathrm{~d}$ & $222.1 \mathrm{abcd}$ & $158.2 \mathrm{c}$ & $211.9 \mathrm{~d}$ \\
\hline Sokal $\mathrm{F}_{1}$ & $244.0 \mathrm{~d}$ & $240.4 \mathrm{~cd}$ & $128.1 \mathrm{abc}$ & $127.9 \mathrm{abc}$ \\
Mieszko $\mathrm{F}_{1}$ & $192.2 \mathrm{abc}$ & $222.2 \mathrm{abcd}$ & $152.5 \mathrm{bc}$ & $133.1 \mathrm{abc}$ \\
\hline Hubal & $196.6 \mathrm{abcd}$ & $225.5 \mathrm{bcd}$ & $149.4 \mathrm{bc}$ & $156.5 \mathrm{c}$ \\
Polset $\mathrm{F}_{1}$ & $188.2 \mathrm{ab}$ & $174.7 \mathrm{a}$ & $170.6 \mathrm{~cd}$ & $93.8 \mathrm{a}$ \\
AF1120 $\mathrm{F}_{1}$ & & & $170.0 \mathrm{~cd}$ & $168.6 \mathrm{~cd}$ \\
Hysioux $\mathrm{F}_{1}$ & & & $169.2 \mathrm{~cd}$ & $108.2 \mathrm{ab}$ \\
Mean & $212.5 \mathrm{~A}$ & $217.0 \mathrm{~A}$ & $156.9 \mathrm{~B}$ & $142.9 \quad \mathrm{~A}$
\end{tabular}

Note: Values marked with the same letter within the same years and means for years do not differ significantly (Tukey's HSD test, $\mathrm{p}<0.05$ )

of ethephon (Table 4). In 2009 the fruits of the 'Hubal' and 'Polset' $F_{1}$ cultivars, taken from the sprayed plots, had higher content of sugars than the control fruits. In 2010 an increase in sugars was noted in the fruits from the 'Rumba', 'Polset' $F_{1}$ and 'Hysioux' $F_{1}$ cultivars sprayed with ethephon, while a decrease was noted in the case of 'Sokal' $F_{1}$ and 'Hubal'. In 2011 ethephon stimulated production of more sugars in the fruits of the 'Sokal' $F_{1}$ and 'Polset' $F_{1}$ cultivars. On average for all cultivars, spraying with ethephon did not affect the content of soluble sugars in the tomatoes in any year of the study.
After application of ethephon the total acidity of the tomatoes increased by $9.1 \%$ in 2009 and by $5.3 \%$ in 2011, but remained unchanged in 2010. In 2009 the total acidity of the fruits increased in response to ethephon in three of the cultivars tested ('Sokal' $F_{1}$, 'Mieszko' $F_{1}$ and 'Polset' $F_{1}$ ), in 2010 only in 'Sokal' $F_{1}$, and in 2011 only in 'AF 1120 ' $F_{1}$ (Table 5).

The use of ethephon did not affect the content of ascorbic acid in the tomatoes in 2009, but in 2010 and 2011 it caused a reduction on the level of $4.9 \%$ and $9.0 \%$ in comparison to the unsprayed tomatoes. Acceleration of tomato ripening thanks to the application of ethephon caused varied responses in individual cultivars. The level of ascorbic acid increased in the sprayed fruits in 2009 of the 'Rumba' and 'Mieszko' $F_{1}$ cultivars, in 2010 of 'Mieszko' $F_{1}$ and 'Polset' $F_{1}$ cultivars, and in 2011 of 'Sokal' $F_{1}$ and 'Polset' $F_{1}$ cultivars, as well (Table 6).

The effect of spraying the tomatoes with ethephon did not significantly influenced the level of lycopene content in the tomatoes harvested in 2009, but it caused an $8.9 \%$ decrease in the content of this pigment in 2010. The level of lycopene in the fruits of individual cultivars in 2009 was not dependent on application of ethephon. In 2010, however, it increased in response to ethephon in the fruits of the 'Rumba' cultivar and decreased in the fruits of the 'Polset' $F_{1}$ and 'Hysioux' $F_{1}$ cultivars (Table 7).

Analysis of the mean content of tomato components in each year of the study reveals no difference in dry matter in 
488

Table 8. Changes in chemical composition of tomato fruits in years of investigation (mean for cultivars and ethephon objects)

\begin{tabular}{lcccccc}
\hline Year & $\begin{array}{c}\text { Dry matter } \\
\text { (\% f.w.) }\end{array}$ & $\begin{array}{c}\text { Extract } \\
\text { (\% f.w.) }\end{array}$ & $\begin{array}{c}\text { Soluble sugars } \\
\text { (\% f.w.) }\end{array}$ & $\begin{array}{c}\text { Acidity } \\
\text { (\% f.w.) }\end{array}$ & $\begin{array}{c}\text { L-ascorbic acid } \\
(\mathrm{mg} \%)\end{array}$ & $\begin{array}{c}\text { Lycopene } \\
\left(\mathrm{mg}^{-1} \cdot \mathrm{kg}^{-1}\right)\end{array}$ \\
\hline 2009 & $5.83 \mathrm{~b}$ & $4.91 \mathrm{~b}$ & $2.01 \mathrm{c}$ & $0.35 \mathrm{a}$ & $19.50 \mathrm{~b}$ & $214.8 \mathrm{~b}$ \\
2010 & $4.81 \mathrm{a}$ & $4.24 \mathrm{a}$ & $1.68 \mathrm{~b}$ & $0.42 \mathrm{c}$ & $19.15 \mathrm{a}$ & $149.9 \mathrm{a}$ \\
2011 & $5.79 \mathrm{~b}$ & $5.03 \mathrm{c}$ & $1.15 \mathrm{a}$ & $0.39 \mathrm{~b}$ & $23.39 \mathrm{c}$ & - \\
\hline
\end{tabular}

Table 9. The cultivar influence on chemical composition of tomato fruits (mean for years and ethephon objects)

\begin{tabular}{|c|c|c|c|c|c|c|}
\hline Cultivar & $\begin{array}{c}\text { Dry matter } \\
\text { (\% f.w.) }\end{array}$ & $\begin{array}{l}\text { Extract } \\
\text { (\% f.w.) }\end{array}$ & $\begin{array}{c}\text { Soluble sugars } \\
\text { (\% f.w.) }\end{array}$ & $\begin{array}{l}\text { Acidity } \\
\text { (\% f.w.) }\end{array}$ & $\begin{array}{c}\text { L-ascorbic acid } \\
(\mathrm{mg} \%)\end{array}$ & $\begin{array}{l}\text { Lycopene } \\
\left(\mathrm{mg} \cdot \mathrm{kg}^{-1}\right)\end{array}$ \\
\hline Rumba & $5.18 \mathrm{a}$ & $4.50 \mathrm{a}$ & $1.59 \mathrm{~cd}$ & $0.37 \mathrm{~b}$ & $24.68 \mathrm{~d}$ & $216.21 \mathrm{~d}$ \\
\hline Sokal F 1 & $5.42 \mathrm{bc}$ & $4.46 \mathrm{a}$ & $1.36 \mathrm{a}$ & $0.37 \mathrm{~b}$ & $19.35 \mathrm{~b}$ & $204.15 \mathrm{~cd}$ \\
\hline Mieszko $F_{1}$ & $5.51 \mathrm{c}$ & $4.56 \mathrm{ab}$ & $1.68 \mathrm{~d}$ & $0.34 \mathrm{a}$ & $17.97 \mathrm{a}$ & $185.73 \mathrm{bc}$ \\
\hline Hubal & $5.72 \mathrm{~d}$ & $5.21 \mathrm{~d}$ & $1.85 \mathrm{e}$ & $0.37 \mathrm{~b}$ & $21.62 \mathrm{c}$ & $191.70 \mathrm{c}$ \\
\hline Polset $F_{1}$ & $5.21 \mathrm{a}$ & $4.63 \mathrm{~b}$ & $1.56 \mathrm{bcd}$ & $0.43 \mathrm{~d}$ & $19.21 \mathrm{~b}$ & $165.04 \mathrm{ab}$ \\
\hline $\mathrm{AF} 1120 \mathrm{~F}_{1}$ & $5.81 \mathrm{~d}$ & $5.04 \mathrm{c}$ & $1.42 \mathrm{abc}$ & $0.47 \mathrm{e}$ & $19.96 \mathrm{~b}$ & $169.32 \mathrm{abc}$ \\
\hline Hysioux $F_{1}$ & $5.28 \mathrm{ab}$ & $4.66 \mathrm{~b}$ & $1.40 \mathrm{ab}$ & $0.41 \mathrm{c}$ & $17.63 \mathrm{a}$ & $138.72 \mathrm{a}$ \\
\hline
\end{tabular}

Note: Values marked with the same letter within the same components do not differ significantly (Tukey's HSD test for unequal N, p < 0.05 ).

Table 10. The ethephon influence on chemical composition of tomato fruits (mean for years and cultivars)

\begin{tabular}{|c|c|c|c|c|c|c|}
\hline Object & $\begin{array}{l}\text { Dry matter } \\
\text { (\% f.w.) }\end{array}$ & $\begin{array}{l}\text { Extract } \\
\text { (\% f.w.) }\end{array}$ & $\begin{array}{c}\text { Soluble sugars } \\
\text { (\% f.w.) }\end{array}$ & $\begin{array}{l}\text { Acidity } \\
\text { (\% f.w.) }\end{array}$ & $\begin{array}{c}\text { L-ascorbic acid } \\
(\mathrm{mg} \%)\end{array}$ & $\begin{array}{l}\text { Lycopene } \\
\left(\mathrm{mg}^{\left.-\mathrm{kg}^{-1}\right)}\right.\end{array}$ \\
\hline Control & $5.42 \mathrm{a}$ & $4.68 \mathrm{a}$ & $1.54 \mathrm{a}$ & $0.38 \mathrm{a}$ & $20.62 \mathrm{~b}$ & $189.6 \mathrm{a}$ \\
\hline Etephon & $5.46 \mathrm{a}$ & $4.74 \mathrm{~b}$ & $1.59 \mathrm{~b}$ & $0.39 \mathrm{~b}$ & $19.82 \mathrm{a}$ & $186.5 \mathrm{a}$ \\
\hline
\end{tabular}

Note: Values marked with the same letter within the same components do not differ significantly (Tukey's HSD test for unequal N, p $<0.05$.

2009 and 2011, but in 2010 it was average of $17.2 \%$ lower than in the other years (Table 8). It was due to the unusually rainy growing season in 2010, in particular heavy and frequent rainfall during the ripening stage period. In that year the lowest content of extract and ascorbic acid in the tomatoes were observed as well: $15.7 \%$ and $19.1 \%$ lower than in 2011 . The highest content of sugars was noted in 2009; in 2011 it was $42.8 \%$ lower. The highest content of organic acids was observed in the tomatoes in 2010, with $16.7 \%$ lower content noted in 2009. The level of lycopene content in the tomatoes harvested in 2009 was $43.3 \%$ higher than in 2010.

Comparison of the averaged results for the content of individual components showed that the 'Hubal' tomatoes had the highest content of dry matter, extract, soluble sugars of all the cultivars tested (Table 9). The highest level of lycopene was noted in the tomatoes of the 'Rumba' and 'Sokal' $F_{1}$ cultivar, ascorbic acid of the 'Rumba' and the highest acidity in 'AF $1120^{\prime} \mathrm{F}_{1}$ tomato cultivar was observed.

Analysis of the ethephon influence on the chemical composition of tomato fruits show that the use of ethephon had no effect on the dry weight of the tomatoes or the content of lycopene in their pulp, but it did cause a $1.3 \%$ increase in extract, a $3.2 \%$ increase in soluble sugars amount, a $2.6 \%$ increase in acidity, and a 3.9\% decrease in ascorbic acid level (Table 10).

\section{Discussion}

Weather conditions have a significant influence on the quality of processing tomatoes.

Content of dry matter is the primary criterion to assess the suitability of tomatoes for processing (Zalewska-Korona and Jabłońska-Ryś, 2012). The higher content of dry matter, the more product can be obtained from the same amount of raw material. Changes in the content of this component after application of the ethephon were a few percent in each year of the study and did not display a uniform tendency. The mean for all cultivars in each year of the study also did not confirm an effect of ethephon on dry matter content of the tomato fruits.

Extract ranging from $4.80 \%$ to $8.80 \%$ f.w. is considered as an indicator of good tomato quality (Moniruzzaman $e t$ al., 2008). During ripening the ratio of extract to organic acids increases; in fully ripe tomatoes it is about 16 and strongly influences acceptance of flavour (Malundo et al., 1995). In the case of the cultivars tested in this experiment, the changes in extract content due to application of ethephon were not uniform, but the mean calculated for the study years and cultivars indicates a small but significant increase in extract after spraying. A study on the 'Feuhong' tomato cultivar showed no effect of ethephon on extract content when it was applied during the mature-green phase (Wanga et al., 2011). Similar results were obtained for 'Hybrid 1001' tomatoes (Dhall and Singh, 2013). Tomatoes of the 'Laura' cultivar treated with ethephon during this phase showed no changes in extract content, but the higher content of this component was noted when the fruits were treated with ethephon in the form of a gas at the breaker stage (Logendra et al., 2004). In our experiment the lowest content of extract was noted in the fruits of the tomatoes harvested in the wet year of 2010, and the highest in 2011, characterized by high and frequent rainfall in July but a very dry August.

Glucose content increases during ripening, mainly due to conversion of starch; fructose also increases slightly, but there is a pronounced reduction in saccharose content (Oms-Oliu et al., 2011). The content of sugars in the tomato fruits can be influenced during the growing period by sunlight, temperature, day length, availability of water, content of minerals, fertilization methods, cutting techniques (Dorais et al., 2008), and even the harvest method (Jauregui et al,. 1999). The lowest content of sugars was observed in the tomatoes in 2011 (with unfavourable weather, i.e. a wet July and dry August), and it was $42.8 \%$ lower than in 2009 (with favourable weather 
conditions for tomato in these months). Spraying with ethephon led to an average increase of $3.2 \%$ in the content of soluble sugars in the tomatoes.

The main organic acids in tomatoes are citric acid and malic acid, which are the most important contributors to the typical flavour of the fruit (Salunkhe et al., 1974). These acids influence $\mathrm{pH}$, which is a key criterion of the quality of tomatoes for processing. In the case of homogenate, $\mathrm{pH}$ should not exceed 4.5 (Anthon et al., 2011). Optimal pH is considered to be 4.25 (Arah et al., 2015).

The most important factor influencing the $\mathrm{pH}$ of tomatoes is temperature. Analysis of 'Feuhong' tomatoes showed no effect of ethephon on the $\mathrm{pH}$ of the pulp when applied at the mature-green stage, but fruit treated with ethephon at the breaker stage showed an increase in $\mathrm{pH}$ (Wanga et al., 2011). A lack of effect of ethephon on the $\mathrm{pH}$ of tomato fruits has also been reported by Renquist et al. (2001). In our experiment, after application of ethephon the average acidity of the tomatoes increase of $2.6 \%$. The highest content of organic acids was noted in the fruits from the wet year of 2010, and the lowest (16.7\% less than in 2010) in the material from 2009, in which the temperature and rainfall were closest to optimal.

The maximum content of ascorbic acid appears in half-ripe tomatoes (the pink stage), after which it declines (Moniruzzaman et al., 2008). Dhall and Singh (2013) report that ethephon caused an increase in the content of ascorbic acid and in titrimetric acidity. In our experiment the content of ascorbic acid in tomatoes ripening under the influence of this preparation was somewhat lower (on average by $1.3 \%$ ). The highest content of this vitamin was noted in the tomatoes in 2011, when it was dry during the ripening phase, and the lowest in 2010, with high levels of rainfall during the ripening phase.

Lycopene content in tomatoes depends on weather conditions during the growing season, the location where the plants are grown, the cultivar, and the degree of ripeness. Temperatures above $32.2{ }^{\circ} \mathrm{C}$ and delayed harvesting of tomatoes lead to a decrease in the content of this pigment (Garcia and Barrett, 2006). A similar result is observed in rainy growing seasons (Helyes et al., 2014). In our experiment, in the near-optimal weather conditions in 2009 the use of ethephon did not affect lycopene content in the tomatoes, but in the wet year of 2010 there was a significant but small decrease of this component.

\section{Conclusions}

A beneficial effect of ethephon was observed in the content of extract, soluble sugars and acidity in the harvested tomatoes. The level of dry matter and lycopene did not depend on the use of this compound, and ascorbic acid was decreased by its application. The chemical composition of the tomato fruits differed significantly between years of the study, confirming the substantial effect of weather conditions on fruit quality and on the varied responses of different cultivars to ethephon. The 'Hubal' cultivar had the highest content of dry matter, extract, soluble sugars of all the cultivars tested. The highest level of lycopene was noted for the tomatoes of the 'Rumba' and 'Sokal' $\mathrm{F}_{1}$ cultivar, ascorbic acid of the 'Rumba' and the highest acidity for 'AF 1120 ' $\mathrm{F}_{1}$.

\section{Acknowledgements}

This work was supported by the grant: 6ZR7 2008 C/07085, "Development and implementation of technology of tomato products with high lycopene content". Research task: BZ 662/KWzEO/09-11.

\section{References}

Anthon GE, LeStrange M, BarrettDM (2011). Changes in pH, acids, sugars and other quality parameters during extended vine holding of ripe processing tomatoes. Journal of the Science of Food and Agriculture 91(7):1175-1181.

Arah IK, Amaglo H, Kumah EK, Ofori H (2015). Preharvest and postharvest factors affecting the quality and shelf life of harvested tomatoes: a mini review. International Journal of Agronomy Article ID 478041.

Beckles DM (2012). Factors affecting the postharvest soluble solids and sugar content of tomato (Solanum lycopersicum L.) fruit. Postharvest Biology and Technology 63:129-140.

Dhall RK, Singh P (2013). Effect of ethephon and ethylene gas on ripening and quality of tomato (Solanum bycopersicum L.) during cold storage. Journal of Nutrition and FoodScience 3(6):1-7.

Dorais M, Ehret DL, Papadopoulos AP (2008). Tomato (Solanum lycopersicum) health components: from the seed to the consumer. Photochemistry Reviews 7:231-250.

Dumas Y, Dadomo M, Di Lucca G, Grolier P (2003). Effects of environmental factors and agricultural techniques on antioxidant content of tomatoes. Journals of the Science of Food and Agriculture 83:369-382.

Garcia E, Barrett DM (2006). Assessing lycopene content in California processing tomatoes. Journal of Food Processing and Preservation 30:56-70.

Gonzalez JV (1999). Use of ethylene (ethephon) in uniform ripening of processing (Lycopersicon esculentum) tomatoes in California. Acta Horticulturae 487:179-182.

Helyes L, Lugasi A, Daood HG, Pék Z (2014). The simultaneous effect of water supply and genotype on yield quantity, antioxidants content and composition of processing tomatoes. Notulae Botanicae Horti Agrobotanici Cluj-Napoca42(1):143-149.

Ilahy R,Hdider Ch,Lenucci MS, Tilil I,Dalessandro G (2011).Antioxidant activity and bioactive compound changes during fruit ripening of highlycopene tomato cultivars. Journal of Food Composition and Analysis 24:588-595.

Jauregui JI, Lumbreras M, Chavarri MJ, Gonzales-Navarro CJ, Macua JI (1999). Dry weight and brix degree correlation in different varieties of tomatoes intended for industrial processing. Acta Horticulturae 487:425-429.

Kevany BM, Taylor M G, Klee HJ (2008). Fruit-specific suppression of the ethylene receptor LeETR 4 results in early-ripening tomato fruit. Plant Biotechnology Journal 6:295-300.

Kmiecik W, Lisiewska Z (2000). Studies on the morphological traits and chemical composition on the fruit of six tomato cultivars recommended as raw material for freezing. Nahrung 44(5):345-353. 
490

Lelievre JM, Latche A, Jones B, Bouzayen M, Pech JC (1997). Ethylene and fruit ripening. Physiologia Plantarum 101(4):727-739.

Li L, Guo M, Wang X, Zang X, Liu T (2016). Effects and mechanism of 1methylcyclopropene and ethephon on softening in Ailsa Craig tomato fruit. Journal of Food Processing and Preservation. doi:10.1111/jfpp.12883.

Logendra LS, Mun JG, Gianfagna TJ, Janes HW (2004). Ethephon concentrates and advances harvest for limited cluster greenhouse tomato crops. HortScience 39(7):1650-1651.

Malundo TMM, Shewfelt RL, Scott JW (1995). Flavor quality of fresh tomato (Lycopersicon esculentum Mill) as affected by sugar and acid levels. Postharvest Biology and Technology 6:103-110.

Moniruzzaman KM, Hossain ABMS, Sani W, Saifuddin M (2008). Effects of stages of maturity and ripening conditions on the biochemical characteristics of tomato. American Journal of Biochemistry and Biotechnology 4(4):336-344.

Moniruzzaman KM, Khatoon R, Hossain MFB, Rahman MT, Alam SN (2015). Influence of ethephon on ripening and quality of winter tomato fruit harvested at different maturity stages. Bangladesh Journal of Agricultural Research 40(4):567-580.

Oms-Oliu G, Hertog MLATM, Van de Poel B, Ampofo-Asiama J, Geeraerd AH, Nicolai BM (2011) Metabolic characterization of tomato fruit during preharvest development, ripening, and postharvest shelf-life. Postharvest Biology and Technology 62:7-16.

Orłowski M, Dobromilska R, Kujath K (2005). The effect of methods accelerating fruit ripening on the yield of small-sized tomato. Folia Horticulturae 17(2):61-69.

Payasi A, Sanwal GG (2010). Ripening of dimacteric fruits and their control. Journal of Food Biochemistry 34:679-710.

Pijanowski E, Dłużewski M, Dłużewska A, Jarczyk A (2004). Ogólna Technologia Żywności, [Food Technology]. WNT Warszawa.

PN-71/A-75101. Przetwory owocowe i warzywne. Przygotowanie próbek i metody badań fizyko-chemicznych. Oznaczanie zawartości witaminy C, [Fruits and vegetables processing. Sample preparation and methods of physico-chemical properties. Determination of vitamin C].
PN-90/A-75101.02 Przetwory owocowe i warzywne. Przygotowanie próbek i metody badań fizykochemicznych. Oznaczanie zawartości ekstraktu ogólnego, [Fruits and vegetables processing. Sample preparation and methods of physico-chemical properties. Determination of total extract].

Renquist AR, English JM, Reid JB (2001). Temperature but not ethephon influences fruit $\mathrm{pH}$ of processing tomato. HortScience 36(4):661-663.

RożekE, Nurzyńska-Wierdak R, Kosior M (2011). Quality and structure of single harvest tomato fruit yield. Acta Scientarum Polonorum, Hortorum Cultus 10(3):319-329.

Saltveit ME (1999). Effect of ethylene on quality of fresh fruits and vegetables. Postharvest Biology and Technology 15:279-292.

Saltveit ME (2005a). Fruit ripening and fruit quality. In: Heuvelink E (Eds). Tomatoes. CABI Publishing, Walllllingford, UK pp 145-159.

Saltveit ME (2005b). Postharvest biology and handling. In: Heuvelink E (Eds). Tomatoes. CABI Publishing, Walllllingford, UK pp 305-324.

Salunkhe DK, Jadhav SJ, Yu MH (1974). Quality and nutritional composition of tomato fruit as influenced by certain biochemical and physiological changes. Plant Foods for Human Nutrition 24:85-113.

Yemm EW, Wills AJ (1954). The estimation of carbohydrates in plant extracts by anthrone. Biochemistry Journal 54:508-514.

Wanga YY,Lia BQ, Qina GZ, Lib L, TianaSP (2011). Defense response of tomato fruit at different maturity stages to salicylic acid and ethephon. Scientia Horticulturae 129(2):183-188.

Zalewska-Korona M, Jabłońska-Ryś E (2012). Ocena przydatności do przetwórstwa owoców wybranych odmian pomidora gruntowego, [Evaluation of processing usefulness of selected fruits of ground tomato cultivars].ŻYWNOŚĆ. Nauka. Technologia.Jakość. 2(81):77-87. 